\title{
Does Money for Grocery Expenditure Sway Italian Consumers' Motivational Values in Predicting Attitude towards Eco- Sustainable Food Products?
}

\author{
Marco Vassallo \\ Council for Agricultural Research and Economics \\ E-Mail: marco.vassallo@entecra.it \\ Anna Saba \\ Council for Agricultural Research and Economics \\ E-Mail: anna.saba@entecra.it
}

\begin{abstract}
This study attempts to explain how the motivational domains of Schwartz's theory of basic human values influence Italian consumers' attitude towards buying eco-sustainable food products and the extent to which the average monthly amount of money available in households for grocery expenditure may modify this influence. A conceptual model of attitude with the high-order dimensions of the Schwartz's taxonomy of human values and past experience as predictors has been hypothesized and performed on a representative sample (i.e., on regional basis and age categories) of Italian food consumers $(n=2760)$. Structural equation modeling (SEM) was used as the methodology. Italian consumers' households with an average monthly amount of less than 400 Euros for grocery expenditures showed universal values and selfenhancement motivations in supporting their positive attitude towards eco-sustainable food products, but with a significant reduction of their openness to change and conservation in disfavor of these products. Consumers with more than 400 Euros showed attenuated universal and conservation values, but with less openness to change and self-enhancement motives. In conclusion, it has seemed that in Italy, where no legal requirements about sustainability have been established yet, being an ethical and universal food consumer still strongly depends on how much money one is able to spend rather than on how ethical or universal one wants to be.
\end{abstract}

Keywords: Attitude towards Behavior, Eco-sustainable Foods, High-order Factors, Schwartz's Theory of Basic Human Values, Structural Equation Modeling 


\section{INTRODUCTION}

It is well accepted that one of the most troubling environmental challenges that mankind has to address concerns its unsustainable consumption patterns and lifestyles (European Environment Agency, 2005; United Nations, 2002). This has inevitably compelled the food industries to improve the environmental performance of food products, the governments to promote policies for the development of eco-sustainable processes (Vermeir \& Verbeke, 2008) and the consumers to contribute to the resolution of ecological and social problems (Schrader \& Thøgersen, 2011). According to Schraefel (2013), who paraphrased Sellahewa and Martindale (2010), the best way to improve sustainability of human-food through the food lifecycle is basically to consume less in terms of "growing consumer demand for better soil practices to consume less energy/resource, understanding food provenance to reduce transport costs of food, reducing food packaging, make more food packaging recyclable, increasing composting of food waste..." (Schraefel, 2013: p. 595). However, these ways of consuming less might appear to be somewhat remote for most consumers (Peattie, 2010). On the other hand, Thøgersen (2010: p. 172) found that the three most effective ways to support sustainability in consumers' food consumption were "1) to reduce the amount of meat, especially beef, in the diet; 2) to buy organic instead of conventionally produced food products; 3) to avoid food products transported by airplane". So, in what way, and in how many ways, do consumers need to behave in order to be sustainable?

Despite the extent of literature on sustainable food consumption, a common understanding of this phenomenon has not yet been reached (Schrader \& Thøgersen, 2011). Moreover, there is not even a clear definition or standard for environmentally friendly products (Sellahewa \& Martindale, 2010), or any common way of putting sustainable food consumption into practice (i.e., consuming many sustainable food products means following a sustainable diet?) (Reisch, Eberle \& Lorek, 2013). Furthermore, the ongoing debate about whether the context (e.g., governmental policies, food companies) or individual consumers' values, attitudes and motivations is more important for accepting sustainability on the whole is still ongoing (Schrader \& Thøgersen, 2011), even though it is generally recognized that consumers have coresponsibility for the consequences of their choices (Hansen \& Schrader, 1997) and that the negative impacts of their consumption patterns need to be reduced in order to achieve sustainability (Schrader \& Thøgersen, 2011).

A concrete result of this unclear situation occurs in Italy where sustainability seems to be mostly seen as synonymous with organic (Biasetti, 2013), even though as it has been stated a while ago buying organic products is not the only way to achieve 
sustainable food consumption. In addition, the Italian government has not yet established any legal requirements (i.e., certification) concerning sustainability but does provide financial incentives to local businesses and regions that may want to apply sustainable farming practices (Biasetti, 2013). Moreover, the government of Italy, like that of other Mediterranean countries, is also in favor of traditional food and has supportive policies for the protection of local specialties as part of the national patrimony and identity (Kurzer \& Cooper, 2007; Thøgersen, 2010). As a result, this sort of two-faced policy strategy (i.e., keeping up traditional food and opening to sustainable food practices) with the consumers' general belief, mainly in the Mediterranean countries, that traditional local food is virtually the same as organic (Roininen, Arvola \& Lahteenmaki, 2006; Thøgersen, 2010), creates further confusion as to whether traditional local foods are the same as organic and whether both are sustainable products.

In this respect, and taking into account the extent to which consumers are willing to pay additional money to support eco-sustainable food products when they are available in the market (Thøgersen, 2010; Vermeir \& Verbeke, 2006, 2008), this study attempts to answer to the following research question: in the presence of this unclear situation about the concept of sustainable food consumption, how much change occurs in the motivational values as predictors of consumers' attitude (consumers' wants) towards eco-sustainable food products when the monthly average amount of money for grocery expenditure differs?

In order to answer this question, an attitude research model has been proposed with both high-order dimensions of Schwartz's theory of basic human values and past experience of purchasing eco-sustainable food products as predictors. The model has been applied to a representative sample on age categories and regional basis of roughly 2,800 Italian food consumers and performed across two groups with different amounts of money for grocery expenditures per month.

\section{LITERATURE REVIEW}

Attitude toward a behavior has been conceptualized as Ajzen and Fishbein's (1980, p. 56) Theories of Reasoned Action (TRA) and Planned Behavior (TPB): “...a person's judgment that performing the behavior is good or bad, that he is in favor of or against performing the behavior." More formally, Ajzen (2005: p. 3) defined attitude as "a disposition to respond favorably or unfavorably to an object, person, institution, or event." Furthermore, attitude has been hypothesized to be composed of having affective and cognitive components that concern the emotional and the practical consequences of performing a behavior, respectively (Ajzen, 2005; 
Langdridge, Sheeran \& Connolly, 2007). So, attitude is a construct that provides information about the affective and cognitive reasons why people want or accept something or someone. This concept of attitude has been widely applied to the context of sustainable food choices (Arvola et al., 2008; Dean, Raats \& Shepherd, 2008; Saba \& Messina, 2003; Tarkiainen \& Sundqvist, 2005; Thøgersen, 2009; Vermeir \& Verbeke, 2008; Zhu et al., 2013). Past experience concerns the role of past behavior and is based on the idea that frequent performance of a behavior leads to the formation of a potential habit that controls subsequent behavior unconsciously (Aarts, Verplanken \& van Knippenberg, 1998) and it can be used as an independent predictor of later action (Ouellette \& Wood, 1998). Past experience in buying products has provided insightful results in the context of organic food choice as well (Thøgersen, 1997; 2009).

Schwartz's $(1992,1994)$ theory of basic human values is a general framework for the study of the value basis of individuals' beliefs, dispositions and behavior. The theory includes ten motivationally distinct motives that are presumed to cover the main value orientations across cultures and constitute a circular structure of motivational opposed and compatible value domains: benevolence, universalism, selfdirection, stimulation, hedonism, achievement, power, security, conformity and tradition. Two orthogonal axes with 4 dimensions organize the 10 value domains: the axis with the two dimensions of "self-enhancement - self-transcendence" places the values of power and achievement (which emphasize the pursuit of self-interests) in opposition to the values of universalism and benevolence (which involve concern for the welfare and interests of others); whilst the axis with the two dimensions of "openness to change - conservation" places the values of self-direction and stimulation (which emphasize independent thought and readiness for new experience) in opposition to the values of security, conformity and tradition (which involve selfrestriction, order and resistance to change). Hedonism shares elements of both "openness to change" and "self-enhancement" dimensions (Schwartz, Sagiv \& Boehnke, 2000; Schwartz et al., 2001). This circular taxonomy of basic human values is depicted in Figure 1. The 10 value domains and the 4 dimensions relate to one another in a circular manner (moving clockwise or counter-clockwise) constituting a continuum that reflects the degree of similarity (adjacent domains/dimensions) or dissimilarity (distant or opposite domains/dimensions) in their underlying motivations. 


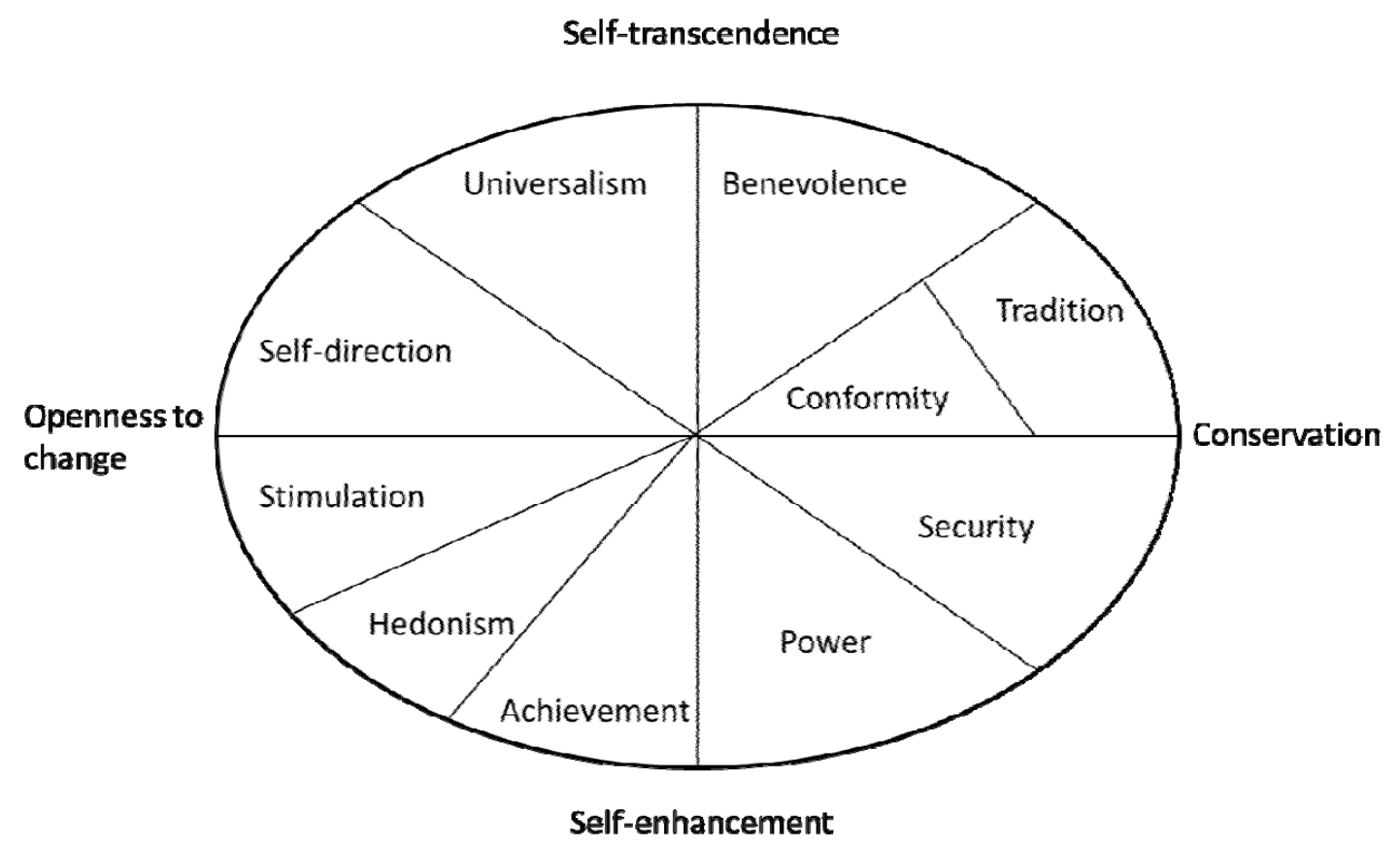

Figure 1 Schwartz's Taxonomy of Motivational Value Domains Adapted from Schwartz (1992)

Analyses of more than 200 samples from more than 60 nations supported the distinctiveness of the 10 values and the circular structure itself (Schwartz 2004a, 2004b; Schwartz et al., 2001; Schwartz \& Sagiv, 1995), even though substantial correlations were found among the motivational value domains that led to an overlapping of the adjacent domains, turning the circular taxonomy into a quasicircumplex, or elliptical, structure (Perrinjaquet et al., 2007; Schwartz \& Boehnke, 2004). Generally, it has been assumed that values are universal in the sense that individuals pursue the same values around the world, but that the relative importance related to different values can vary (Rokeach, 1973; Schwartz \& Bilsky, 1987). However, values are usually understood as extremely stable constructs that are not easily changed, even though this topic is always under investigation. As a result, values can be seen as good predictors of behavior over extended periods of time. Consequently, values, beliefs and attitudes can form a hierarchical structure. It is commonly believed that causality flows from values through beliefs to attitudes and then to behavior. Hence, it is not surprising that the concept of human values has been widely used by social scientists to explain a variety of attitudinal and behavioral outcomes. Wedel, ter Hofstede and Steenkamp (1998) claimed that these outcomes include concepts as diverse as charity contributions, religious behavior, cultural orientation, participation in civil rights activities, drug addiction, political orientation, 
innovativeness and purchase of environmentally friendly products. Furthermore, Peter, Olson and Grunert (1999) supported the view that consumers' value priorities are assumed to determine the importance of expected consequences of their choices, such as attitudes. Incidentally, Jager (2000) proposed a conceptual framework to investigate behavior towards sustainable food products with personal values as determinants of both attitude and behavioral intention.

\section{OBJECTIVES AND HYPOTHESES}

The present study focused on the predictive ability of the dimensions of Schwartz's taxonomy of basic human values and past experience as determinants of attitude towards buying eco-sustainable food products together with the extent to which these predictors may differ across two groups of average monthly amount of grocery expenditures.

The procedural analytical path will be explained by the research model, depicted in Figure 2, with the following two hypotheses:

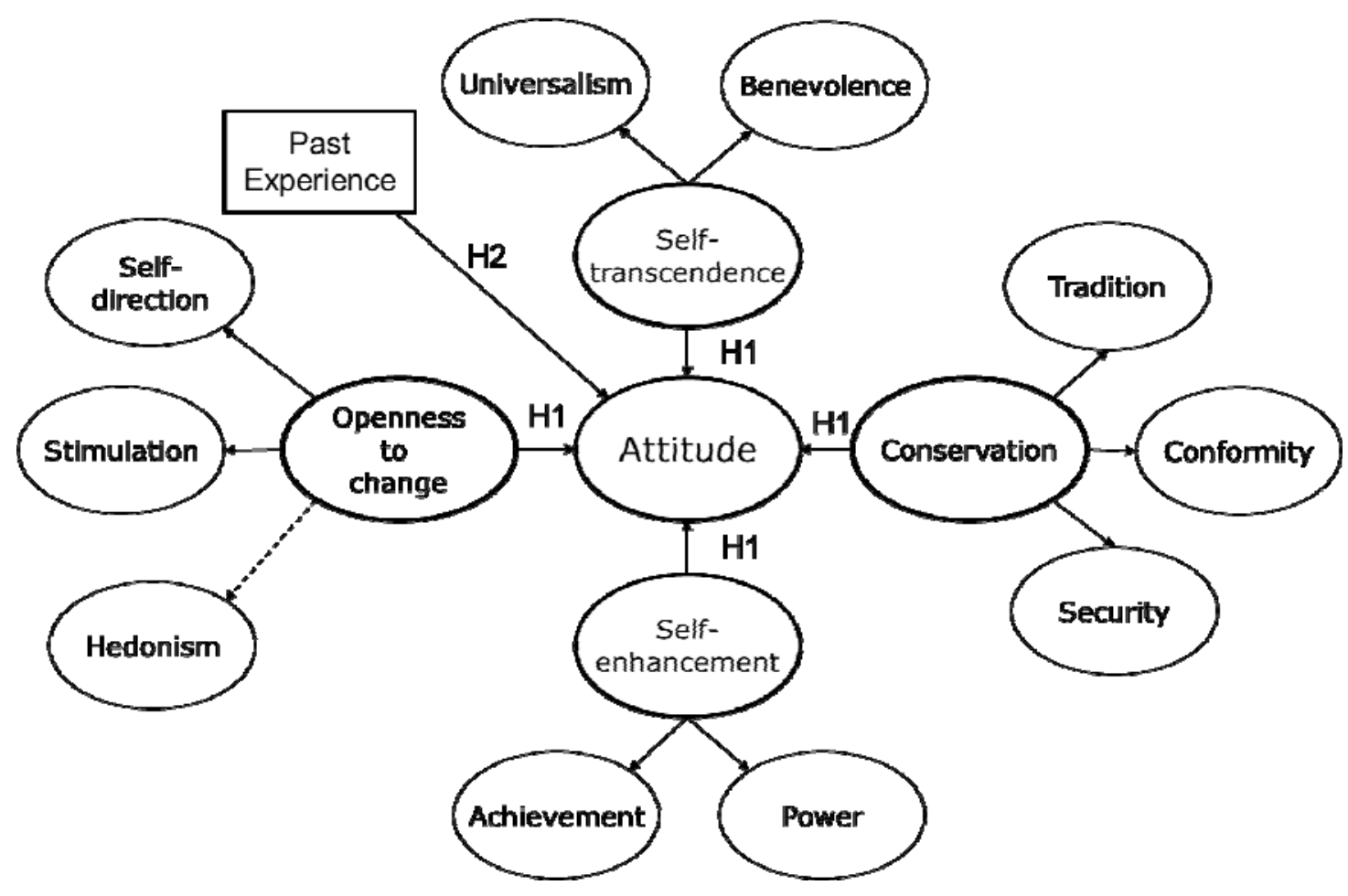

Figure 2 Conceptual Model of Attitude toward a Behavior

Hypothesis 1 (H1): Attitude toward a behavior is predicted by basic human values dimensions. This hypothesis is supported by Schwartz' theory of human 
values, which defines values as the most abstract level of cognition, non-specific in relation to situations or objects, but influencing the perception and evaluation of them. Values are therefore thought to be the criteria people use as guidelines for evaluating stimuli (i.e., situations, persons and objects) and they serve, as Rokeach (1973) claimed, as 'standards' or models for attitudes, beliefs and behavior. Furthermore, due to the elliptical shape of Schwartz' taxonomy, strong correlations between adjacent domains (i.e., first-order constructs) will be expected (Schwartz et al., 2012); therefore, four high-order dimensions (i.e., second-order constructs) will be hypothesized in order to make the structure more meaningful (Schwartz \& Boehnke, 2004).

Hypothesis 2 (H2): Attitude toward a behavior is predicted by past experience in performing that behavior. This hypothesis is supported by past research (Hagger, Chatzisarantis \& Biddle 2001; Thøgersen, 1997, 2009) that has seen this repeated behavior as the antecedent of many social cognitive predictors, and not just attitude, in performing a behavior.

\section{METHOD}

\section{Sample}

Data were collected in June 2011 from a professional agency (PRAGMA market research company) using a three-step quota-based sampling method. In the first step, the sample quota was designed to be representative on a regional basis of age categories using data from the census performed in 2001 by the Italian National Institute of Statistics (i.e., ISTAT). Then, in the second step, national sampling points were partially randomized since they included the biggest 45 municipalities in Italy in respect of the aforementioned regional stratification. Finally, in the third step, within each sampling point, a random sample of households (addresses) was visited by interviewers (applying random-walk procedures) selecting only one member of the family if over 18 years of age and solely, or jointly, responsible for the family's food expenditure. A structured self-administered questionnaire was handed out to each selected respondent. Subsequently, subjects were contacted by phone to arrange an appointment for handing in the completed questionnaire. The final sample was comprised of 3,004 respondents with a mean age of 48 years where more than half the participants were females (i.e., $60 \%$ females, $40 \%$ males), $45 \%$ with high school educational level, $31 \%$ with primary education completed, $14 \%$ with university degree ( $1.4 \%$ with postgraduate degree), $9 \%$ with no formal or less than primary education, and $0.3 \%$ were missing. 


\section{Measures in The Questionnaire}

In the present study, a validated Italian version of the Portrait Value Questionnaire (PVQ) questionnaire was used (Capanna, Vecchione \& Schwartz, 2005). The PVQ with 40 items typology, including descriptions of 40 different hypothetical respondents, is one of the instruments that was developed to measure these values (Schwartz 2004a, 2004b; Schwartz et al., 2001). Each description implicitly points to the importance of a value; for example: "He really wants to enjoy life. Having a good time is important to him" describes a person to whom hedonist values are important. The question: "How much like you is this person?" accompanies each description. Responses are: "very much like me," "like me," "somewhat like me," "a little like me, "not like me" and "not like me at all." The number of descriptions/items for each value are: 6 for universalism; 5 for security; 4 for tradition, conformity, benevolence, self-direction and achievement; and 3 for stimulation, hedonism and power. By doing so, all 40 items of the PVQ questionnaire were presented to the respondents with categories labelled "very much like me" (coded as 6), "like me" (coded as 5), "somewhat like me" (coded as 4), "a little like me" (coded as 3), "not like me" (coded as 2), and "not like me at all" (coded as 1).

Attitudes towards buying eco-sustainable food products were measured with three items (Vermeir \& Verbeke, 2008): "Buying eco-sustainable food products is" (bad/good; unwise/wise and useless/meaningful) with coding from 1 to 7.

Past experience of behavior was measured by one item taken and adapted from Hagger et al. (2001) and Bamberg, Ajzen and Schmidt (2003): "How often have you bought sustainable food products in the past 6 months?" (hardly ever, seldom, occasionally, often, very often, always) with coding from 1 to 6 .

One item was used to measure the average amount of money for grocery expenditure: "What is the average amount of money for grocery expenditure in your household per month? (Euro)" (less than 200 Euros, 201-400 Euros, 401-600 Euros, over 600 Euros). These four categories were successively combined in two groups: "less than 400 Euros" comprised the first two categories, whereas "more than 400 Euro" comprised the last two. The reason for this classification was based on the fact that currently in Italy a family spends, on average, around 400 Euros per month at the grocery store (i.e., 468.32 Euros; source: ISTAT, 2012).

\section{DATA ANALYSIS}

The causal relationships among the 10 motivational domains of human values, attitude and past experience factors were analyzed using SEM (Bollen, 1989; Jöreskog \& Sörbom, 2002) with the maximum likelihood (ML) method of estimation. In all 
SEM analyses, cases with incomplete information were deleted using listwise deletion. The missing values were found under 5\% within each single variable. The cut-off of $5 \%$ of missing may be considered marginal while dealing with large samples(Kline, 2011). Confirmatory factor analyses (CFAs) were performed (before defining the structural relations) in order to achieve the convergent and discriminant validity among constructs (Kline, 2011) and then to validate the measurement model (Anderson \& Gerbing, 1988). All CFAs (and the subsequent structural models) were performed by fixing one loading of one arbitrary indicator to 1 for each different factor (i.e., latent variable) in order to define the scale of the factor itself (Kline, 2011). Additionally, as suggested by Schermelleh-Engel, Moosbruger and Müller (2003) and Jöreskog and Sörbom (2002), a standardized residual analysis was conducted for all CFA models adding double-arrowed paths between those error covariances where the correspondent standardized residuals were high (more than \pm 1.96 with $\mathrm{p}<.05$; or \pm 2.58 with $\mathrm{p}<.01$ ), the relative modification index was very large (more than \pm 3.84 with $\mathrm{p}<.05$; or \pm 6.63 with $\mathrm{p}<.01$ ) and, most importantly, while taking into account construction and theoretical reasons ${ }^{1}$ (Schermelleh-Engel et al., 2003). The high-order (second-order in our study) latent constructs ${ }^{2}$ were successively hypothesized by the existence of substantial correlations between factors (Bagozzi \& Heatherton, 1994; Fabricar et al., 1999). In the present study, the second-order factors are represented by the four dimensions of Schwartz's taxonomy (i.e., selftranscendence, conservation, openness to change, self-enhancement; see Fig. 1) loaded by the connected domains at first-order level (see Fig. 2).

Multi-sample confirmatory factor analysis (MS-CFA) was performed to check for cross-cultural validity between two groups of grocery expenditure at the first- and second-order levels. Cross-cultural validity refers to the extent to which data collected by the same multi-item measurement instrument are comparable across different cultural environments (Bredahl, 2001). Configural and metric invariance ${ }^{3}$ of the measures are necessary to make cross-group comparisons of structural path coefficients meaningfully well (Steenkamp \& Baumgartner, 1998). The analyses were conducted using LISREL 8.80 for Windows (Jöreskog \& Sörbom, 2007) and SPSS v20.0.

\footnotetext{
${ }^{1}$ The essential modifications regarded items very similarly worded in loading the same theoretical concept. In order to preserve space, these analyses will be not shown, but they can be obtained from the first author.

${ }^{2}$ Strictly speaking, the second-order factor models are those in which correlations among the first-order factors can be represented by a single factor, or at least a smaller set of factors. Likewise, if correlations among the second-order factors can be represented by another factor (or smallest set of factors), then a third-order model exists, and so on (Byrne, 1998).

${ }^{3}$ Configural and metric invariance, respectively, mean that the same underlying constructs are measured in all groups and the observed variables are measured according to the same scale units (Scholderer, 2007).
} 


\section{RESULTS}

\section{Preliminary Analysis}

The descriptive statistics and the Cronbach's alpha coefficients were calculated ${ }^{4}$ for each measured variable and factor, respectively. The effective sample size was of 2,797. The values of Cronbach's alpha were found to be around 0.8 and 0.9 with a few exceptions around 0.64 and 0.70 . Attitude towards eco-sustainable food products was, on average, positive for all three measures (i.e., negative/positive: mean score 5.98 $(\mathrm{SD}=1.18)$; unwise/wise: mean score $6.00(\mathrm{SD}=1.20)$; useless/meaningful: mean score 5.96 ( $\mathrm{SD}=1.21)$. Normality checks on the measured variables found the distributions to have kurtosis and skewness quite close to $|1|$ with some indices $>|1|$ but under $|2|$ (results not shown, but available from the first author). However, high non-normality is usually associated with kurtosis $>7$ and skewness $>2$ (Boomsma \& Hoogland, 2001; West, Finch \& Curran, 1995).

The CFAs' goodness of fit indices of the Schwartz taxonomy at the first-order level (i.e., Normal Theory Weighted Least Squares Chi-Square (df $=689)$ : 6635.26, $\mathrm{p}<0.001, \mathrm{RMSEA}=0.056, \mathrm{CFI}=0.96$, TLI-NNFI=0.96. $\mathrm{SRMR}=0.054)$ and at the second-order level (i.e., Normal Theory Weighted Least Squares Chi-Square $(\mathrm{df}=721): \quad 8701.54, \quad \mathrm{p}<0.001, \quad \mathrm{RMSEA}=0.063, \quad \mathrm{CFI}=0.95, \quad$ TLI-NNFI=0.95. $\mathrm{SRMR}=0.075)$ were quite good according to the cut-off criteria. ${ }^{5}$ All factor loadings were significantly and substantially different from zero and over 0.50 , indicating convergent validity (Kline, 2005), so that all the average variances extracted (AVE) were found to be above the recommended level of 0.5 (Hair, Ringle \& Sarstedt, 2011) (results not shown, but available from the first author). The estimated zero-order correlations among the first- and second-order factors are reported in Table 1. Usually, correlations over 0.70 indicate that a problem of multi-collinearity may exist (Bryman \& Cramer, 1990; Tabachnick \& Fidell, 1996), even though the cut-off of 0.85 is still showing evidence of distinctiveness of the factors (Kline, 2011). Nevertheless, the estimated correlations greater than 0.85 might indicate that the indicators underlying

\footnotetext{
${ }^{4}$ Values of $0.7,0.8,0.9$ are considered to be "adequate", "very good" and "excellent", respectively (Kline, 2005). Values over 0.6 are recommended (Bagozzi \& Yi, 1988). The complete results of alpha values together with descriptive statistics are not reported here in order to preserve space but are available from the first author.

${ }^{5}$ The general model's fit was assessed by: a) the Normal Theory Weighted Least Squares Chi-Square (NT ChiSquare) as a descriptive goodness of fit index for nested models (Jöreskog \& Sörbom, 2002); commonly, low and not-significant Chi-Square values are a sign of a good fit; b) the Comparative Fix Index (CFI), the NonNormed Fit Index (TLI - NNFI) the Root Mean Square Error of Approximation (RMSEA), the Standardized Root Mean Squared Residual (SRMR) are reported. Values greater than 0.90 for CFI and TLI-NNFI were considered adequate for a good model fit (Bentler, 1990) although values approaching and over 0.95 were preferred (Hu \& Bentler, 1999). Values of RMSEA equal to or less than 0.05 were considered a good fit (Hu \& Bentler, 1999), in the range between 0.05 to 0.08 were considered marginal, and greater than 0.10 were considered a poor fit (Browne \& Cudeck, 1993). In good models, the SRMR should be below 0.09 (Hu \& Bentler, 1999).
} 
these constructs were measuring and loading on the same factors, thereby making discriminant validity difficult to achieve. On the other hand, those high correlations are both related to the adjacent domains of the Schwartz's taxonomy and connected to the four high-order dimensions. All of this was expected, confirming both the quasicircumplex structure of the 10 motivational domains and the ability of the elliptical taxonomy to form high-order dimensions that are able to describe the value structure more simply (Schwartz \& Boehnke, 2004). A global CFA comprehending all the factors involved in the attitude model (see Fig. 2) was successfully performed confirming good fit in terms of convergent and discriminant validity along with satisfactory diagnostics (all of these results are available from the first author). Since the past experience variable was measured with a single item, it required the application of the so-called "piecewise identification rule" (Bollen \& Davis, 2009) to be meaningfully introduced into the attitude model (i.e., exploring the relative zeroorder correlation with the other factors). By doing so, past experience was barely programmed as a latent factor measured by a single indicator (Brown, 2006). This latter statement technically means that latent variables measured with a single indicator are assumed to be measured without error - since the measurement error cannot be estimated - and the error variance is necessarily fixed at zero. Table 2 depicts the results of the measurement invariance across the two groups of average amount of grocery expenditures for first- and second-order factor models. The effective sample size was of 2,760. The first-order CFA model concerned all the variables, while the second-order CFA model concerned only the domains and dimensions of the Schwartz's human values. Configural invariance was assessed by looking for identical factor patterns (Steenkamp \& Baumgartner, 1998) in the CFAs performed simultaneously across the two groups. The fit indices of both configural invariances were satisfactory, implying that the survey instrument measures the same underlying latent constructs in the two groups for both the first- and second-order models (see Table 2).

To achieve metric invariance (at least partial), the literature stipulates that at least one factor loading per latent variable (in addition to the one fixed at unity to define the scale of each latent construct) must be metrically invariant (be equal) (Steenkamp \& Baumgartner, 1998). Full metric invariances (all factor loadings constrained to be equal across groups) were performed. The global goodness of fit indices ${ }^{6}$ of the full

\footnotetext{
${ }^{6}$ The chi-square difference test is usually applied to compare nested models; however, the limitations of this latter index are well-known (e.g., violation of multi-normality assumptions, model complexity, sample size; Schermelleh-Engel et al., 2003). Consequently, other fit indices, especially the Akaike's Information Criterion (AIC) in simulation studies (Williams \& Holahan, 1994), were used as an alternative method and as further
} 
metric models were compared with those of the configural invariance. Full metric invariances were supported since all the fit indices basically stayed the same and the Chi-square difference tests were not significant. Thus the un-standardized ${ }^{7}$ solutions of the subsequent attitude model may be compared across the two groups meaningfully well.

Table 1 Estimated Zero-Order Correlations among $1^{\text {st }}$ and $2^{\text {nd }}$ Order Factors

$$
(n=2797)
$$

\begin{tabular}{|c|c|c|c|c|c|c|c|c|c|c|c|c|c|c|}
\hline & \multicolumn{10}{|c|}{ First-order Factors } & \multicolumn{4}{|c|}{ Second-order Factors } \\
\hline & $\mathbf{U}$ & B & $\mathbf{T}$ & C & $\mathbf{S}$ & $\mathbf{P}$ & $\mathbf{A}$ & $\mathbf{H}$ & St & S-d & S-t & Co & S-e & O-t-c \\
\hline $\mathbf{U}$ & 1 & & & & & & & & & & & & & \\
\hline B & 0.83 & 1 & & & & & & & & & & & & \\
\hline $\mathbf{T}$ & 0.57 & 0.63 & 1 & & & & & & & & & & & \\
\hline $\mathbf{C}$ & 0.78 & 0.78 & 0.88 & 1 & & & & & & & & & & \\
\hline $\mathbf{S}$ & 0.76 & 0.66 & 0.78 & 0.90 & 1 & & & & & & & & & \\
\hline $\mathbf{P}$ & -0.16 & -0.04 & 0.01 & 0.02 & 0.14 & 1 & & & & & & & & \\
\hline A & 0.08 & 0.20 & 0.09 & 0.20 & 0.29 & 0.93 & 1 & & & & & & & \\
\hline $\mathbf{H}$ & 0.13 & 0.25 & 0.07 & 0.19 & 0.23 & 0.65 & 0.78 & 1 & & & & & & \\
\hline St & 0.17 & 0.27 & 0.01 & 0.13 & 0.20 & 0.70 & 0.84 & 0.94 & 1 & & & & & \\
\hline S-d & 0.68 & 0.67 & 0.25 & 0.52 & 0.60 & 0.43 & 0.62 & 0.66 & 0.80 & 1 & & & & \\
\hline S-t & 0.93 & 0.90 & 0.70 & 0.83 & 0.77 & 0.07 & 0.07 & 0.29 & 0.32 & 0.26 & 1 & & & \\
\hline Co & 0.78 & 0.75 & 0.84 & 0.99 & 0.92 & 0.17 & 0.18 & 0.21 & 0.23 & 0.19 & 0.83 & 1 & & \\
\hline S-e & 0.07 & 0.06 & 0.15 & 0.18 & 0.17 & 0.92 & 1.00 & 0.73 & 0.80 & 0.67 & 0.07 & 0.18 & 1 & \\
\hline O-t-c & 0.30 & 0.29 & 0.20 & 0.23 & 0.22 & 0.75 & 0.81 & 0.91 & 0.99 & 0.82 & 0.32 & 0.23 & 0.81 & 1 \\
\hline
\end{tabular}

Note: $\mathrm{U}=$ Universalism; $\mathrm{B}=$ Benevolence; $\mathrm{T}=$ Tradition; $\mathrm{C}=$ Conformity; $\mathrm{S}=$ Security; $\mathrm{P}=$ Power; $\mathrm{A}=$ Achievement; $\mathrm{H}=$ Hedonism; $\mathrm{St}=$ Stimulation; $\mathrm{S}-\mathrm{d}=$ Self-direction; $\mathrm{S}-\mathrm{t}=$ Self-transcendence; $\mathrm{Co}=$ Conservation; S-e=Selfenhancement; O-t-c=Openness to change.

\section{The Attitude Model}

According to the results from CFAs and measurement invariance, the previously hypothesized attitude model (see Fig. 2) with the two key hypotheses was analyzed for the two groups of expenditure and for the whole sample (see Table 3). Attitude towards eco-sustainable food products was still, on average, positive in both groups for all three measures (i.e., group <400: 1) negative/positive: mean score 5.52 ( $\mathrm{SD}=$ $1.47)$; 2) unwise/wise: mean score 5.57 ( $\mathrm{SD}=1.42)$; 3) useless/meaningful: mean score $5.40(\mathrm{SD}=1.57$; group $>400: 1)$ negative/positive: mean score $5.67(\mathrm{SD}=$ 1.48); 2) unwise/wise: mean score $5.72(\mathrm{SD}=1.44) ; 3)$ useless/meaningful: mean score $5.61(\mathrm{SD}=1.52)$.

support for the model comparison test as recommended by Steenkamp and Baumgartner (1998). The model associated with the lowest AIC is considered the optimal and most parsimonious model (Rigdon, 1999).

${ }^{7}$ The un-standardized estimates are usually appropriate for cross-group comparisons, whereas the standardized estimates are directly comparable only across different variables within each sample (Kline, 2011). 
Table 2 Summary of Multi-Sample CFA Models Fit Statistics for Assessing Configural and Metric Measurement Invariance (*only for Schwartz's taxonomy)

\begin{tabular}{|c|c|c|c|c|}
\hline & \multicolumn{2}{|c|}{ First-order CFA model } & \multicolumn{2}{|c|}{ Second-order CFA model* } \\
\hline & $\begin{array}{l}\text { Configural } \\
\text { Invariance }\end{array}$ & $\begin{array}{l}\text { Full Metric } \\
\text { Invariance }\end{array}$ & $\begin{array}{l}\text { Configural } \\
\text { Invariance }\end{array}$ & $\begin{array}{l}\text { Full Metric } \\
\text { Invariance }\end{array}$ \\
\hline NT Chi-Square & 8010.27 & 8054.67 & 8747.19 & 8804.30 \\
\hline$d f$ & 1662 & 1694 & 1399 & 1432 \\
\hline $\begin{array}{l}\text { NT-Chi-Square } \\
\text { (difference) }\end{array}$ & \multicolumn{2}{|c|}{$\begin{array}{l}\Delta \Delta(\mathbf{C}, \mathbf{M})=44.4 \\
\text { (not significant at the } 95 \% \text { confidence } \\
\text { level) Chi-Sq }(32 ; 0.05)=46.19\end{array}$} & \multicolumn{2}{|c|}{$\begin{array}{c}\qquad \Delta(\mathbf{C}, \mathbf{M})=57.11 \\
\text { (not significant at the } 99.9 \% \text { confidence } \\
\text { level) Chi-Sq }(33 ; 0.001)=63.87\end{array}$} \\
\hline $\mathrm{AIC}$ & 8646.27 & 8626.67 & 9229.19 & 9220.30 \\
\hline SRMR & 0.058 & 0.059 & 0.059 & 0.061 \\
\hline RMSEA & 0.053 & 0.052 & 0.061 & 0.061 \\
\hline CFI & 0.96 & 0.96 & 0.96 & 0.96 \\
\hline TLI - NNFI & 0.96 & 0.96 & 0.95 & 0.95 \\
\hline
\end{tabular}

Table 3 Unstandardized Solutions (Standardized between Brackets) $-\left({ }^{*}\right.$ not Significant at the $95 \%$ Confidence Level)

\begin{tabular}{|c|c|c|c|c|c|c|c|c|c|c|}
\hline \multicolumn{3}{|c|}{ Factor Loadings } & & & & & & \multicolumn{3}{|c|}{ Path Coefficients } \\
\hline $\begin{array}{c}\text { Whole } \\
\text { Sample } \\
\text { (Italy) } \\
\mathrm{n}=2760\end{array}$ & $\begin{array}{c}<400 \\
\text { Euros } \\
\mathrm{n}=1729 \\
63 \%\end{array}$ & $\begin{array}{c}>400 \\
\text { Euros } \\
\mathrm{n}=1031 \\
37 \%\end{array}$ & \multicolumn{2}{|c|}{$\begin{array}{l}\text { First- } \\
\text { order } \\
\text { domains }\end{array}$} & \multicolumn{2}{|c|}{$\begin{array}{c}\text { Second- } \\
\text { order } \\
\text { dimensions }\end{array}$} & Criterion & $\begin{array}{c}<400 \\
\text { Euros } \\
\mathrm{n}=1729 \\
63 \%\end{array}$ & $\begin{array}{c}>400 \\
\text { Euros } \\
\mathrm{n}=1031 \\
37 \%\end{array}$ & $\begin{array}{c}\text { Whole } \\
\text { Sample } \\
\text { (Italy) } \\
\mathrm{n}=2760\end{array}$ \\
\hline $\begin{array}{c}1.00 \\
(1.00) \\
\end{array}$ & $\begin{array}{c}1.00 \\
(1.00) \\
\end{array}$ & $\begin{array}{c}1.00 \\
(1.00)\end{array}$ & P-E & $\leftarrow$ & P-E & $\rightarrow$ & \multirow{11}{*}{$\begin{array}{c}\text { Attitude } \\
\text { Towards } \\
\text { Buying } \\
\text { Sustainable } \\
\text { Food } \\
\text { Products }\end{array}$} & $\begin{array}{c}0.42 \\
(0.39)\end{array}$ & $\begin{array}{c}0.47 \\
(0.43)\end{array}$ & $\begin{array}{c}0.45 \\
(0.41)\end{array}$ \\
\hline $\begin{array}{c}1.00 \\
(0.96) \\
\end{array}$ & $\begin{array}{c}1.00 \\
(0.96) \\
\end{array}$ & $\begin{array}{c}1.00 \\
(0.95)\end{array}$ & $\mathrm{U}$ & $\leftarrow$ & \multirow{2}{*}{ S-t } & \multirow{2}{*}{$\rightarrow$} & & 1.74 & 1.00 & 1.39 \\
\hline $\begin{array}{c}0.86 \\
(0.87) \\
\end{array}$ & $\begin{array}{c}0.85 \\
(0.88) \\
\end{array}$ & $\begin{array}{c}0.90 \\
(0.86) \\
\end{array}$ & B & $\leftarrow$ & & & & $(0.96)$ & $(0.49)$ & $(0.73)$ \\
\hline $\begin{array}{c}1.00 \\
(0.99) \\
\end{array}$ & $\begin{array}{c}1.00 \\
(1.00)\end{array}$ & $\begin{array}{c}1.00 \\
(0.99)\end{array}$ & $\mathrm{C}$ & $\leftarrow$ & \multirow{3}{*}{ Co } & \multirow{3}{*}{$\rightarrow$} & & \multirow{3}{*}{$\begin{array}{c}-1.11 \\
(-0.59)\end{array}$} & \multirow{3}{*}{$\begin{array}{c}-0.44 \\
(-0.23)\end{array}$} & \multirow{3}{*}{$\begin{array}{c}-0.77 \\
(-0.41)\end{array}$} \\
\hline $\begin{array}{c}0.91 \\
(0.84) \\
\end{array}$ & $\begin{array}{c}0.91 \\
(0.84) \\
\end{array}$ & $\begin{array}{c}0.92 \\
(0.86) \\
\end{array}$ & $\mathrm{T}$ & $\leftarrow$ & & & & & & \\
\hline $\begin{array}{c}0.93 \\
(0.92) \\
\end{array}$ & $\begin{array}{c}0.98 \\
(0.92) \\
\end{array}$ & $\begin{array}{c}0.83 \\
(0.92) \\
\end{array}$ & S & $\leftarrow$ & & & & & & \\
\hline $\begin{array}{c}1.00 \\
(0.94) \\
\end{array}$ & $\begin{array}{c}1.00 \\
(0.90) \\
\end{array}$ & $\begin{array}{c}1.00 \\
(0.96) \\
\end{array}$ & $P$ & $\leftarrow$ & \multirow{2}{*}{ S-e } & \multirow[b]{2}{*}{$\rightarrow$} & & \multirow{2}{*}{$\begin{array}{c}0.30 \\
(0.21)\end{array}$} & \multirow{2}{*}{$\begin{array}{c}-0.12^{*} \\
(-0.09)\end{array}$} & \multirow{2}{*}{$\begin{array}{l}-0.16^{*} \\
(-0.24)\end{array}$} \\
\hline $\begin{array}{c}1.22 \\
(0.95)\end{array}$ & $\begin{array}{c}1.29 \\
(1.00)\end{array}$ & $\begin{array}{c}1.26 \\
(1.00)\end{array}$ & A & $\leftarrow$ & & & & & & \\
\hline $\begin{array}{c}1.04 \\
(0.91)\end{array}$ & $\begin{array}{c}1.04 \\
(0.93)\end{array}$ & $\begin{array}{c}1.03 \\
(0.87)\end{array}$ & $\mathrm{H}$ & $\leftarrow$ & \multirow{3}{*}{ O-t-c } & \multirow{3}{*}{$\rightarrow$} & & \multirow{3}{*}{$\begin{array}{c}-0.33 \\
(-0.24)\end{array}$} & \multirow{3}{*}{$\begin{array}{c}0.03^{*} \\
(0.02)\end{array}$} & \multirow{3}{*}{$\begin{array}{c}0.10^{*} \\
(0.08)\end{array}$} \\
\hline $\begin{array}{c}1.00 \\
(0.99)\end{array}$ & $\begin{array}{c}1.00 \\
(1.00)\end{array}$ & $\begin{array}{c}1.00 \\
(0.99)\end{array}$ & $\mathrm{St}$ & $\leftarrow$ & & & & & & \\
\hline $\begin{array}{c}0.47 \\
(0.83) \\
\end{array}$ & $\begin{array}{c}0.48 \\
(0.85) \\
\end{array}$ & $\begin{array}{c}0.43 \\
(0.79) \\
\end{array}$ & S-d & $\leftarrow$ & & & & & & \\
\hline & & & & & & & $\mathrm{R}^{2}=$ & 0.50 & 0.40 & 0.46 \\
\hline
\end{tabular}

Note: $\mathrm{U}=$ Universalism; $\mathrm{B}=$ Benevolence; $\mathrm{C}=$ Conformity; $\mathrm{T}=$ Tradition; $\mathrm{S}=$ Security; $\mathrm{P}=$ Power; $\mathrm{A}=$ Achievement; $\mathrm{H}=$ Hedonism; $\mathrm{St}=$ Stimulation; $\mathrm{S}-\mathrm{d}=$ Self-direction; $\mathrm{P}-\mathrm{E}=$ Past-Experience; $\mathrm{S}-\mathrm{t}=$ Self-transcendence; $\mathrm{Co}=$ Conservation; $\mathrm{S}-\mathrm{e}=$ Self-enhancement; $\mathrm{O}-\mathrm{t}-\mathrm{c}=$ Openness to change. 
In terms of goodness of fit indices, all models performed well (i.e., group $<400$ Euros: Normal Theory Weighted Least Squares Chi-Square ( $\mathrm{df}=874)$ : 6133.96, $\mathrm{p}<0.001, \mathrm{RMSEA}=0.059, \mathrm{CFI}=0.96$, TLI-NNFI $=0.95, \mathrm{SRMR}=0.074$; group $>400$ Euros: Normal Theory Weighted Least Squares Chi-Square ( $\mathrm{df}=875)$ : 4119.27, $\mathrm{p}<0.001$, RMSEA $=0.060, \mathrm{CFI}=0.95$, TLI-NNFI $=0.95$. SRMR $=0.077$; whole sample (Italy): Normal Theory Weighted Least Squares Chi-Square ( $\mathrm{df}=876$ ): 9274.06, $\mathrm{p}<0.001, \mathrm{RMSEA}=0.059, \mathrm{CFI}=0.96$, TLI-NNFI $=0.95 . \mathrm{SRMR}=0.074)$ together with a reasonable amount of explained attitude variance, $50 \%, 40 \%$ and $46 \%$ respectively. Unstandardized factor loadings in relation to the first-order domains were all significant and similar across the two groups with the exception of the security domain that decreased its support in the conservation dimension while shifting toward the group with more than 400 Euros (i.e., from 0.98 to 0.83; see Table 3). Past experience played an equal role in predicting attitude towards buying eco-sustainable food products and therefore functioned independently from how much money the consumers were able to spend on groceries, on average, per month in their household. On the other hand, the Schwartz's dimensions of human values played a pretty different, substantial and, in some cases, opposite role. More specifically, the attitude of the respondents who may spend under 400 Euros on groceries in their household was positively guided by values of self-transcendence and self-enhancement (stronger than the ones in the whole sample), but negatively guided by values of conservation and openness to change (always stronger than the ones in the whole sample). Interestingly, when moving to the possibility of spending more than 400 Euros, the influence of values on consumers' attitude was attenuated with a decrease of selftranscendence and conservation (although these two dimensions preserved the positive and negative signs, respectively, but less than the ones in the whole sample as well) up to a not significant effect on both self-enhancement and openness to change. Motivations of self-transcendence (i.e., universalism and benevolence) were the strongest predictors of attitude in both groups (see standardized solution in Table 3) hierarchically followed by conservation, past experience, openness to change and selfenhancement for the group with less than 400 Euros and by past experience, conservation, self-enhancement and openness to change for the group with more than 400 Euros.

\section{DISCUSSION AND CONCLUSION}

The present study contributed to understanding how motivational values may determine the attitude towards eco-sustainable food products in Italy and, in turn, how consumers modified their support when the household's monthly average grocery 
expenditure constituted a barrier. The motivational dimension of self-transcendence (i.e., universalism and benevolence) was the strongest, and the most expected (Thøgersen, 2001; Vermeir \& Verbeke, 2008) motive in determining why Italian consumers may be inclined to buy this type of products. Italian consumers were, however, generally characterized by conservation values regarding food products since the conservation dimension (i.e., tradition, conformity and safety) negatively influenced their attitude towards eco-sustainable food products. This latter result was also expected since Italian consumers, and therefore the Italian government with its protection policies (Thøgersen, 2010), strongly consider the local foods as part of their national culture (Parasecoli, 2004). It was interesting to observe the structure of the values for the category of consumers with an average amount of grocery expenditures less than 400 Euros. These consumers, in comparison to those of the other category of expenditure, revealed stronger values of self-transcendence, self-enhancement (i.e., power and achievement) and conservation together with less motivation of openness to change. As a consequence, their high sense of universalism and benevolence seemed to greatly influence their attitude towards eco-sustainable food products because it strongly opposed an openness to change (which turned into closeness to change) and conservation values together with searching for power-achievement with declaring to be in favor of sustainability. This conclusion was also supported by the impact of past experience on attitude while buying eco-sustainable food products that was found to be essentially the same, although slightly less, in comparison to that of consumers with much more money. Accordingly, the possibility of high premium prices did not seem to affect positive experiences of rewarding consequences in buying these products. On the contrary, if consumers had money to spend on groceries, they seemed 'willing to take the trouble' to buy sustainable food products since their motivational values reduced their influence on attitude still preserving a good deal of self-transcendence, nevertheless. So, it seems that with money the consumer might also be more interested in ethical food behavior. These results also confirmed the general empirical evidence that "it is often claimed that people overreport environmentally friendly behaviors" (Thøgersen \& Olander, 2006: p. 564). But, most importantly, these findings seem to lead to the following conclusion: lacking a clear practical understanding of what sustainable food consumption stands for, not even from the government's point of view (i.e., policies), creates misgivings and unwillingness in consumers to buy sustainable food products. In such situations, money could make the difference: 1) in the group with less than 400 Euros, the availability of money turns their motivational motives to the "old trade" of conservation and closeness to change, even though they want to appear to be 
"sustainable" consumers and potentially ready to overcome possibly high premium prices; 2) in the group with more than 400 Euros, the availability of money leads to a potential indifferent attitude towards sustainability. All things considered, this study has sought to provide empirical evidence that a positive attitude towards ecosustainable food products should not be diminished, at least in Italy, by having, or not having, money available for grocery expenditures since the purpose of this typology of products should go beyond the mere availability of "cash". But, by doing so, sustainable food consumption needs more knowledge and more action (Thøgersen \& Schrader, 2012). So, strong efforts need to be made by the scientific community to promote deeper understanding of what it practically means to be a sustainable consumer. This could lead to an even more univocal governmental sustainable policy. If scientists, policymakers, and the food industry do not work in the same direction for an integrated policy on sustainable development, paradoxical situations about ecosustainable food products might seriously occur at the level of consumers' attitude (wants), at least in Italy where the motto may continue to be "no money, no ethics."

\section{LIMITATIONS AND FUTURE CHALLENGES}

One limitation of this study is that the proposed model did not consider behavioral beliefs as antecedents of attitude toward a behavior. For future research, this set of beliefs should be examined and added to a full model with attitudes and values. Furthermore, and in parallel with an attitude model, a more rigorous sociocognition model with actual behavior and behavioral intention to buy real ecosustainable food products should be hypothesized, so as to offer a more exhaustive view on the consumer decision-making process regarding these products.

\section{ACKNOWLEDGEMENTS}

This study was conducted with financial support from the Italian Ministry for Agricultural, Food, and Forestry Policies (MiPAAF) project REGALIM, which is an acronym that means "monitoring the dietary habits of each main geographical area of Italy - characterization of territory and social structure for responsible food consumption to safeguard the culture and traditions." Furthermore, this study does not necessarily reflect, and in no way anticipates, the MiPAAF future policy in this area. 


\section{REFERENCES}

Aarts, H., Verplanken, B., \& Knippenberg, A. (1998). Predicting behavior from actions in the past: Repeated decision making or a matter of habit? Journal of Applied Social Psychology, 28(15), 1355-1374. http://dx.doi.org/10.1111/j.15591816.1998.tb01681.x

Ajzen, I. (2005). Attitudes, personality, and behavior (2nd. Edition). Milton-Keynes, England: Open University Press, McGraw- Hill.

Ajzen, I., \& Fishbein, M. (1980). Understanding Attitudes and Predicting Social Behavior. Englewood Cliffs, NJ: Prentice-Hall.

Anderson, J. C., \& Gerbing, D.W. (1988). Structural equation modeling in practice: A review and recommended two-step approach. Psychological Bulletin, 103(3), 411423. http://dx.doi.org/10.1037/0033-2909.103.3.411

Arvola, A., Vassallo, M., Dean, M., Lampila, P., Saba, A., Lähteenmäki, L., Shepherd, R. (2008). Predicting intentions to purchase organic food: The role of affective and moral attitudes in the theory of planned behaviour. Appetite, 50(2), 443-454. http://dx.doi.org/10.1016/j.appet.2007.09.010

Bagozzi, R.P., \& Heatherton, T.F. (1994). A general approach to representing multifaceted personality constructs: Applications to state self-esteem. Structural Equation Modeling, 1(1), 35-67. http://dx.doi.org/10.1080/10705519409539961

Bagozzi, R.P., \& Yi, Y. (1988). On the evaluation of structural equation models. Journal of the Academy of Marketing Science, 16(1), 74-94. http://dx.doi.org/10.1007/BF02723327

Bamberg, S., Ajzen, I., \& Schmidt, P. (2003). Choice of travel mode in the theory of planned behavior: The roles of past behavior, habit, and reasoned action. Basic $\begin{array}{llll}\text { and Applied Social } & \text { Psychology, 25(3), }\end{array}$ http://dx.doi.org/10.1207/S15324834BASP2503_01

Bentler, P.M. (1990). Comparative fit indexes in structural models. Psychological Bulletin, 107(2), 238-246. http://dx.doi.org/10.1037/0033-2909.107.2.238

Biasetti, D. (2013). Italy and Sustainable Agriculture Overview. Retrieved from http:/gain.fas.usda.gov/Recent\%20GAIN\%20Publications/Italy\%20and\%20Susta inable\%20Agriculture\%20Overview\%20_Rome_Italy_2-11-2013.pdf

Bollen, K.A. (1989). Structural Equations with Latent Variables, NY: Wiley.

Bollen, K.A., \& Davis, W.R. (2009). Causal indicator models: Identification, estimation, and testing. Structural Equation Modeling: A Multidisciplinary Journal, 16(3), 498-522. http://dx.doi.org/10.1080/10705510903008253

Boomsma, A., \& Hoogland, J.J. (2001). The robustness of LISREL modelling revisited. In R. Cudeck, S. Du Toit, D. Sörbom (Eds.), Structural Equation 
Modeling: Present and Future (pp. 139-164), Chicago, IL: Scientific Software International Inc.

Bredahl, L. (2001). Determinants of consumer attitudes and purchase intentions with regard to genetically modified foods-results of a cross-national survey. Journal of Consumer Policy, 24(1), 23-61. http://dx.doi.org/10.1023/A:1010950406128

Brown, T.A. (2006). Confirmatory Factor Analysis for Applied Research, New York: The Guilford Press.

Browne, M.W., \& Cudeck, R. (1993). Alternative ways of assessing model fit. In K. A. Bollen and J. S. Long (Eds.), Testing Structural Equation Models (pp. 136-162), Newbury Park, CA: Sage.

Bryman, A., \& Cramer, D. (1990). Quantitative Data Analysis for Social Sciences, London: Routledge.

Byrne, B.M. (1998). Structural Equation Modeling with LISREL, PRELIS and SIMPLIS: Basic Concepts, Applications, and Programming, Mahwah, NJ: Lawrence Erlbaum Associates Publishers.

Capanna, C., Vecchione, M., \& Schwartz S.H. (2005). The measurement of values: A contribution to the validation of the Portrait Value Questionnaire on an Italian sample. Bollettino di Psicologia Applicata, 246, 29-41.

Dean, M., Raats, M.M., \& Shepherd, R. (2008). Moral concerns and consumer choice of fresh and processed organic foods. Journal of Applied Social Psychology, 38, (8), 2088-2107.

European Environment Agency. (2005). Household consumption and the environment. Copenhagen, Denmark: European Environment Agency.

Fabricar, L.R., Wegener, D.T., MacCallum, R.C., \& Strahan, E.J. (1999). Evaluating the use of exploratory factor analysis in psychological research. Psychological Methods, 4(3), 272-299. http://dx.doi.org/10.1037/1082-989X.4.3.272

Hagger, M.S., Chatzisarantis, N., Biddle, S.J.H. (2001). The influence of self-efficacy and past behaviour on the physical activity intentions of young people. Journal of Sports Sciences, 19(9), 711-725. http://dx.doi.org/10.1080/02640410152475847

Hair, J.F, Ringle, C.M., \& Sarstedt, M. (2011). PLS-SEM: Indeed a silver bullet. Journal of Marketing Theory and Practice, 19(2), 139-152. http://dx.doi.org/10.2753/MTP1069-6679190202

Hansen, U., \& Schrader, U. (1997). A Modern Model of Consumption for a Sustainable Society. Journal of Consumer Policy, 20(4), 443-468.

Hu, L., \& Bentler, P.M. (1999). Cutoff criteria for fit indexes in covariance structure analysis: Conventional criteria versus new alternatives. Structural Equation Modeling, 6(1), 1-55. http://dx.doi.org/10.1080/10705519909540118 
ISTAT. (2012). Rapporto annuale 2012 - La situazione del Paese. Istituto nazionale di statistica. Roma ISBN 978-88-458-1719-9. Retrieved from: http://dati.istat.it/Index.aspx?DataSetCode=DCCV_SPEMMFAM\&Lang=en

Jager, W. (2000). Modelling Consumer Behaviour. PhD thesis, University of Groningen, Groningen.

Jöreskog, K., \& Sörbom, D. (2002). LISREL 8: Structural Equation Modeling with the Simplis Command Language, Fifth Printing. Lincolnwood, IL: Scientific Software International Inc.

Jöreskog, K., \& Sörbom, D. (2007). LISREL 8.80 for Windows, Chicago, IL: Scientific Software International Inc.

Kline, B.R. (2005). Principles and Practice of Structural Equation Modeling, (Second Edition). NY: The Guilford Press.

Kline, B.R. (2011). Principles and Practice of Structural Equation Modeling, (Third Edition). NY: The Guilford Press.

Kurzer, P., \& Cooper., A. (2007). What's for dinner? European farming and food traditions confront American biotechnology. Comparative Political Studies, 40(9), 1035-1058.

Langdridge, D., Sheeran, P., \& Connolly, K.J. (2007). Analyzing Additional Variables in the Theory of Reasoned Action. Journal of Applied Social Psychology, 37(8), 1884-1913. http://dx.doi.org/10.1111/j.1559-1816.2007.00242.x

Ouellette, J.A., \& Wood, W. (1998). Habit and intention in everyday life: The multiple processes by which past behavior predicts future behavior. Psychological Bulletin, 124(1), 54-74. http://dx.doi.org/10.1037/0033-2909.124.1.54

Perrinjaquet, A., Furrer, O., Usunier, J. C., Cestre, G., \& Valette-Florence, P. (2007). A test of the quasi-circumplex structure of human values. Journal of Research in Personality, 41(4), 820-840. http://dx.doi.org/10.1016/j.jrp.2006.10.006

Parasecoli, F. (2004). Food Culture in Italy. Westport: Greenwood Press.

Peattie, K. (2010). Green Consumption: Behavior and Norms. Annual Review of Environment and Resources, 35(1), 195-228. http://dx.doi.org/10.1146/annurevenviron-032609-094328

Peter, J.P., Olson, J.C., \& Grunert, K.G. (1999). Consumer Behaviour and Marketing Strategy. European edition. London: McGraw Hill.

Reisch, L., Eberle, U., \& Lorek, S. (2013). Sustainable food consumption: an overview of contemporary issue and policies. Sustainability: Science, Practice \& Policy, 9(2), 7-25. 
Rigdon, E. E. (1999). Using the Friedman method of ranks for model comparison in structural equation modeling. Structural Equation Modeling: A Multidisciplinary Journal, 6(3), 219-232. http://dx.doi.org/10.1080/10705519909540131

Roininen, K., Arvola, A., \& Lähteenmäki, L. (2006). Exploring consumers' perceptions of local food with two different qualitative techniques: Laddering and word association. Food Quality and Preference, 17(1), 20-30. http://dx.doi.org/10.1016/j.foodqual.2005.04.012

Rokeach, M. (1973). The Nature of Human Values, The Free Press: New York, NY.

Saba, A., \& Messina, F. (2003). Attitudes towards organic food and risk/benefit perception associated with pesticides, Food quality and Preference, 14(8), 637645. http://dx.doi.org/10.1016/S0950-3293(02)00188-X

Schermelleh-Engel, K., Moosbruger, H., \& Müller, H. (2003). Evaluating the fit of structural equation models: Test of significance and descriptive goodness-of-fit measures. Methods of Psychological Research - Online, 8(2), 23-74.

Scholderer, J. (2007). Measurement invariance of the Portrait Values Questionnaire across 25 European countries. Paper presented at 12th Cross-Cultural Research Conference, Honolulu, HI, United States, 12-15 December, 2007.

Schrader, U., \& Thøgersen, J. (2011). Putting Sustainable Consumption into Practice. Journal of Consumer Policy, 34(1), 3-8. http://dx.doi.org/10.1007/s10603-0119154-9

Schraefel, M.C. (2013). Green Food Through Green Food: A Human Centered Design Approach to Green Food Technology. UbiComp'13 Adjunct, September 8-12, 2013, Zurich, Switzerland. http://dx.doi.org/10.1145/2494091.2499623

Schwartz, S.H. (1992). Universals in the content and structure of values: Theoretical advance and empirical tests in 20 countries. Advances in Experimental Social Psychology, 25, 1-65. http://dx.doi.org/10.1016/S0065-2601(08)60281-6

Schwartz, S.H. (1994). Are there universal aspects in the content and structure of values? Journal of Social Issues, 50(4), 19-45. http://dx.doi.org/10.1111/j.15404560.1994.tb01196.x

Schwartz, S.H. (2004a). Basic human values: Their content and structure across countries. In A. Tamayo and J. Porto, Valores e Trabalho (Values and Work). Brasilia: Editora Universidade de Brasilia, Brasilia.

Schwartz, S.H. (2004b). Robustness and fruitfulness of a theory of universals in individual values. In A. Tamayo and J. Porto, Valores e Trabalho (Values and Work). Brasilia: Editora Universidade de Brasilia, Brasilia. 
Schwartz, S.H., \& Bilsky, W. (1987). Toward a universal psychological structure of human values. Journal of Personality and Social Psychology, 53(3), 550-562. http://dx.doi.org/10.1037/0022-3514.53.3.550

Schwartz, S.H., \& Boehnke, K. (2004). Evaluating the structure of human values with confirmatory factor analysis. Journal of Research in Personality, 38(3), 230-255. http://dx.doi.org/10.1016/S0092-6566(03)00069-2

Schwartz, S.H., \& Sagiv, L. (1995). Identifying culture specifics in the content and structure of values. Journal of Cross Cultural Psychology, 26(1), 92-116. http://dx.doi.org/10.1177/0022022195261007

Schwartz, S.H., Sagiv, L., \& Boehnke, K. (2000). Worries and values. Journal of Personality, 68(2), 309-346. http://dx.doi.org/10.1111/1467-6494.00099

Schwartz, S.H., Melech, G., Lehman, A., Burgess, S., Harris, M., \& Owens, V. (2001). Extending the cross-cultural validity of the theory of basic human values with a different method of measurement. Journal of Cross Cultural Psychology, 32(5), 519-542. http://dx.doi.org/10.1177/0022022101032005001

Schwartz, S.H., Cieciuch, J., Vecchione, M., Davidov, E., Fischer, R., Beierlein, C., Ramos, A., Verkasalo, M., \& Lönnqvist, J-R., Demirutku, K., \& Dirilen-Gumus, O., Konty, M. (2012). Refining the theory of basic individual values. Journal of Personality and Social Psychology, 103(4), 663-688. http://dx.doi.org/10.1037/a0029393

Steenkamp, J-B.E.M., \& Baumgartner, H. (1998). Assessing measurement invariance in cross-national consumer research. Journal of Consumer Research, 25(1), 78-90. http://dx.doi.org/10.1086/209528

Sellahewa, J.N., \& Martindale, W. (2010). The impact of food processing on the sustainability of the food supply chain. Delivering food security with supply chain led innovations: understanding supply chains, providing food security, delivering choice. Royal Holloway, Egham, UK, 7-9 September 2010. Association of Applied Biologists, 91-97.

Tabachnick, B.G., \& Fidell, L.S. (1996). Using multivariate statistics, New York: Harper \& Row.

Tarkiainen, A., \& Sundqvist, S. (2005). Subjective norms, attitudes and intentions of Finnish consumers in buying organic food. British Food Journal, 107(11), 808822. http://dx.doi.org/10.1108/00070700510629760

Thøgersen, J. (1997). Understanding behaviours with mixed motives. An application of a modified theory of reasoned action on consumer purchase of organic food products. Paper presented at the ACR European Conference, Stockholm, 25-28 June, 1997. 
Thøgersen, J. (2001). Consumer values, behaviour and sustainable development. Asia Pacific Advances in Consumer Research, 4, 207-209.

Thøgersen, J. (2009). Consumer decision-making with regard to organic food products. In Teresa de Noronha Vaz, Peter Nijkamp and Jean-Louis Rastoin (Eds.). Traditional Food Production Facing Sustainability: A European Challenge (pp. 173-194). Farnham: Ashgate.

Thøgersen, J. (2010). Country Differences in Sustainable Consumption: The Case of Organic Food. Journal of Macromarketing, 30(2), 171-185.

Thøgersen, J., \& Olander, F. (2006). To what degree are environmentally beneficial choices reflective of a general conservation stance? Environment and Behavior, 38(4), 550-569.

Thøgersen, J., \& Schrader, U. (2012). From Knowledge to Action - New Paths Towards Sustainable Consumption. Journal of Consumer Policy, 35, 1-5.

United Nations. (2002). The Johannesburg declaration on sustainable development. United Nations. Retrieved from

http://www.un.org/jsummit/html/documents/summit_docs/131302_wssd_report_reissued .pdf

Vermeir, I., \& Verbeke, W. (2006). Sustainable food consumption: exploring the consumer "attitude-behavioural intention" gap. Journal of Agricultural and Environmental Ethics, 19, 169-194.

Vermeir, I., \& Verbeke, W. (2008). Sustainable food consumption among young adults in Belgium: Theory of planned behaviour and the role of confidence and values. Ecological Economics, 64(3), 542-553. http://dx.doi.org/10.1016/j.ecolecon.2007.03.007

Wedel, M., ter Hofstede, F., Steenkamp, J-B.E.M. (1998). Mixture model analysis of complex samples. Journal of Classification, 15(2), 225-244, 1998. http://dx.doi.org/10.1007/s003579900032

West, S.G., Finch, J.F., \& Curran, P.J. (1995). Structural Equation Models with nonnormal variables: Problems and remedies. In R. H. Hoyle (Ed.), Structural Equation Modelling: Concepts, Issues and Applications (pp. 56-75). Newbury Park, CA: Sage.

Williams, L.J., \& Holahan, P.J. (1994). Parsimony-based fit indices for multipleindicator models: Do they work? Structural Equation Modeling, 1(2), 161-189. http://dx.doi.org/10.1080/10705519409539970

Zhu, Q., Li, Y., Geng, Y., \& Qi, Y. (2013). Green food consumption intention, behaviors and influencing factors among Chinese consumers. Food Quality and Preference, 28, 279-286. http://dx.doi.org/10.1016/j.foodqual.2012.10.005 